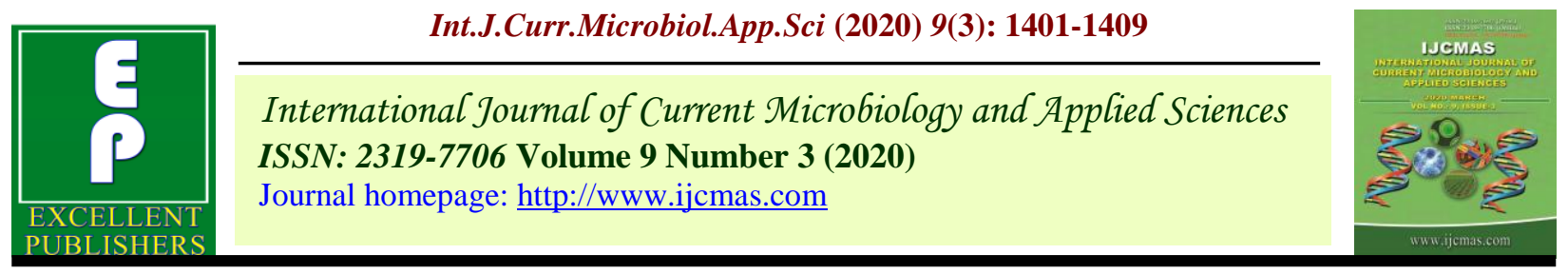

Original Research Article

https://doi.org/10.20546/ijcmas.2020.903.163

\title{
Fertility Status of Sewage Irrigated Soils of Adjoining Areas of Nathnager Blocks, Bhagalpur District, India
}

\author{
Sneha $^{1}$, Raj Kishore Kumar ${ }^{1 *}$, Y. K. Singh ${ }^{1}$, Shweta Shambhavi ${ }^{1}$ and M. K. Singh ${ }^{2}$ \\ ${ }^{1}$ Department of Soil Science and Agricultural Chemistry, Bihar Agricultural University, \\ Sabour, Bhagalpur-813210, India \\ ${ }^{2}$ Department of Agronomy, Bihar Agricultural University, Sabour, Bhagalpur-813210, India \\ *Corresponding author
}

\section{A B S T R A C T}

\begin{tabular}{|l|}
\hline Ke y w o r d s \\
$\begin{array}{l}\text { Fertility. } \\
\text { organic carbon, } \\
\text { crops limits }\end{array}$ \\
\hline Article Info \\
\hline $\begin{array}{l}\text { Accepted: } \\
\text { 12 February } 2020 \\
\text { Available Online: } \\
\text { 10 March } 2020\end{array}$ \\
\hline \hline
\end{tabular}

The present investigation was carried out on "Fertility status of adjoining areas from sewage irrigated soils in Nathnager blocks(Bhagalpur district), India. The $\mathrm{pH}$ and EC content of selected pedon (P1 to P6) varied from 7.33 to 8.8.15 (with the mean value 7.94) and 0.03 to $0.12 \mathrm{dSm}^{-1}$ (with the mean value 0.07 ), respectively. The soil organic carbon content of selected pedon (P1 to P9) varied between 0.23 to 1.24 (with the mean value 0.60 ). The nitrogen content of selected pedon (P1 to P9) varied from 100 to $200 \mathrm{~kg}$ ha-1 (with mean $164 \mathrm{Kg}$ ha-1) indicated that most of the belong to deficient in status. Whereas, available phosphate content of selected pedon (P1 to P9) varied from 15 to $154 \mathrm{~kg} \mathrm{ha}^{-1}$ (with mean $90 \mathrm{Kg} \mathrm{ha}^{-1}$ ) indicated that most of the belong to low too high in status. The available potash content of selected pedon (P1 to P9) varied from 313 to $850 \mathrm{~kg} \mathrm{ha}^{-1}$ (with mean $441 \mathrm{Kg} \mathrm{ha}^{-1}$ ) indicated that most of the belong to high in status. Overall, we can conclude that fertility status of adjoining areas from sewage irrigated soils having medium to high status. However, choice of crops limits due to toxicity of unwanted foreign material. These types of soil can be used after proper treatment.

\section{Introduction}

Globally about 20 million hectares of arable land are irrigated with waste water (Aydin et al., 2015).The population of India is 1.33 billion with a population density of 460 per square kilometers (United Nation, 2019). About 15,644 million liters per day (MLD) sewage generated from 35 metropolitan cities (more than one million populations) in India
(CPCB, 2013). Total sewage treatment capacity at existing likely to be around 12 billion liters per day but total sewage generation from urban centers is approximate 38 billion liters per day in India.

Whereas, the domestic and municipal fresh water (both surface and groundwater) demand in India by 2025 and 2050 will be about 55 and $90 \mathrm{Bm}^{3}$, respectively (NCIWRD, 1999). 
Bhagalpur (Silk city) is the second largest city in economy and the third biggest city of Bihar. Bhagalpur stands towards production of Oak Tassar Silk and its products. Nathnager area in Bhagalpur district is the focal point of various industries viz., silk industry, battery industry, electroplating, and automobile repairing unit.

The growth of the towns has also triggered the progression of the industrial sector and effluents from these sectors finally find their way by making sewage sludge. The effluents discharge from these sources and directly dispose in ChampaNala which eventually mixes up with the holy river Ganga, degrade the soil and water quality.

From fertility point of view, produce obtain from farmers field should be investigate properly not only quality but also consider the quality. Keeping the above facts in mind, present investigation has been carried out on "Fertility status of adjoining areas from sewage irrigated soils in Nathnager blocks (Bhagalpur district), India”.

\section{Materials and Methods}

Bhagalpur is located at 25.24 latitude and 86.97 longitude, and lies in southeastern part of Bihar and northeastern part of India. The climate of Bhagalpur is warm and temperate. The average annual temperature is $25.8^{\circ} \mathrm{C}$; about $1111 \mathrm{~mm}$ of precipitation falls annually. Field survey of three villages namely Kalupur, Basantpur and Mathurapur village of Nathnager block in Bhagalpur district, Bihar was carried out through traversing to collect representative soil samples from various layers in sewage irrigated soils samples belongs to farmer's field which are being used in growing vegetables.

Soil samples were collected from three major vegetable growing areas located in Nathnagar block i.e., Kalupur, Mathurapur and Basantpur during December 2018. The sites were subjected to heavy metal contamination because the sewage of whole city is discharged in ChampaNala. The farmers in these areas use wastewater obtained from Champanala (fully contaminated) for irrigation purpose.

The three different locations that were selected for sewage irrigated adjoining areas of Champanala pool were (1) Rampur (2) Basantpur and (3) Mathurapur. The soil samples were collected at different depth i.e., (0-15, 15-30, 30-45, 45-60, and 60-90 cm) with the help of stainless-steel hand-trowel. The trowel was carefully cleaned after each sampling exercise, to avoid crosscontamination. $250 \mathrm{gm}$ of soils from each depth were collected in a plastic bag and numbering of samples was done on each plastic bag. The collected composite samples were dried in an oven at $105^{\circ} \mathrm{C}$ for $24 \mathrm{hrs}$. The samples were milled and sieved out particles of $<2 \mathrm{~mm}$ for the analysis.

The soil reaction $(\mathrm{pH})$ and electrical conductivity were measured in 1:2.5 (Soil: Water) suspension methodology followed by Jackson et al., (1973). Organic carbon of soil was estimated by chromic acid wet digestion method given by Walkley and Black (1934). The available nitrogen of estimated in presence of alkaline potassium permanganate solution and determining the ammonia liberated (Subbiah and Asija, 1956).

The soil was extracted with $0.5 \mathrm{M}$ Sodium bicarbonate at $\mathrm{pH} 8.5$ through blue colour method by visible double beam spectrophotometer (Olsen et al., 1965).Ammonium exchanges with $\mathrm{K}^{+}$on the soil colloids and the extract contains exchangeable and water-soluble $K$, the amount of which was determined by using flame photometer (Hanway and Heidel, 
1952). The statistical analysis has been done by Gomez and Gomez (1984).

\section{Results and Discussion}

\section{Physio-chemical properties}

In Kalupur village, the $\mathrm{pH}$ of pedon varied from 7.33 to 8.15 with a mean value of $\mathrm{pH}$ 7.94. The maximum value of $\mathrm{pH}$ (8.15) was found in pedon 1 at a depth of $60-90 \mathrm{~cm}$ while the minimum value of $\mathrm{pH}$ (7.33) was found at a depth of $60-90 \mathrm{~cm}$ in pedon2. In Basantpur village, the $\mathrm{pH}$ in soils varied from 8.00 to 8.25 with a mean value of 8.09 . The maximum value of $\mathrm{pH}(8.25)$ was found at a depth of $45-60 \mathrm{~cm}$ in pedon5 while the minimum value of $\mathrm{pH}(8.00)$ was found at a depth of $0-15 \mathrm{~cm}$ in pedon 4 .

Similarly, in Mathurapur village it was observed that the $\mathrm{pH}$ of pedon varied from 6.27 to 8.24 (moderately alkaline) with a mean value of 7.94 (slightly alkaline). The maximum value of $\mathrm{pH}$ (8.24) was found at depth of $60-90 \mathrm{~cm}$ in $\mathrm{P}_{7}$ and $\mathrm{P}_{9}$. Whereas the minimum value of $\mathrm{pH}$ (6.27) was observed at a depth of $30-45 \mathrm{~cm}$ in $\mathrm{P}_{7}$. Overall; it was observed that there was no evidence for regular trend was found towards soils $\mathrm{pH}$ with respect to soil depth. However, soilreaction of some selected pedon in Nathnager block were varied from 6.25 to 8.25 with mean 7.99.Overall, results indicated that, soils belong to Nathnager block from selected pedon was neutral to alkaline condition.

Results further observed that, $\mathrm{pH}$ decreases with increasing depth with few exceptions of some part of layers in selected pedon. It may be due to translocation of bases from upper layers (Sharma et al., 2004). The high value of soils of selected pedon was due to deposition of calcium nodule and it justify the active calcium carbonate was higher in predominant areas.
In Kalupur village, the EC of pedon soils varied from 0.03 to $0.12 \mathrm{dS} \mathrm{m}^{-1}$ with a mean value of $0.07 \mathrm{dS} \mathrm{m}^{-1}$. The maximum value of EC $\left(0.12 \mathrm{dS} \mathrm{m}^{-1}\right)$ was found at a depth of 45$60 \mathrm{~cm}$ in pedon 3 . While, minimum value of EC $\left(0.03 \mathrm{dS} \mathrm{m}^{-1}\right)$ was found at a depth of 45 $60 \mathrm{~cm}$ in pedon1. In Basantpur village, the EC of pedon varied from 0.03 to $0.12 \mathrm{dS} \mathrm{m}^{-1}$ with a mean value of $0.09 \mathrm{dS} \mathrm{m}^{-1}$.

The maximum value of EC $\left(0.12 \mathrm{dS} \mathrm{m}^{-1}\right)$ was found at a depth of $0-15 \mathrm{~cm}$ in pedon $\mathrm{P}_{5}$ and $\mathrm{P}_{6}$. While, minimum value $\left(0.03 \mathrm{dS} \mathrm{m}^{-1}\right)$ was found in pedon at a depth of $30-45 \mathrm{~cm}$ in $\mathrm{P}_{4}$ and $\mathrm{P}_{6}$. Similarly, the EC of pedon varied from 0.05 to $0.15 \mathrm{dS} \mathrm{m}^{-1}$ with a mean value of $0.10 \mathrm{dS} \mathrm{m}^{-1}$ in Mathurapur village. The maximum value of EC $\left(0.15 \mathrm{dS} \mathrm{m}^{-1}\right)$ was found in pedon $\mathrm{P}_{7}$ at a depth of $0-15 \mathrm{~cm}$ while the minimum value of EC $\left(0.05 \mathrm{dS} \mathrm{m}^{-1}\right)$ was found in pedon $\mathrm{P}_{9}$ at a depth of $60-90 \mathrm{~cm}$. Hence, the trend observed was found to be irregular.

However, EC (total dissolved salt) of some selected pedon in Nathnager block were varied from $0.03 \mathrm{dS} \mathrm{m}-1$ to $0.15 \mathrm{dS} \mathrm{m}^{-1}$ with mean value $0.08 \mathrm{dS} \mathrm{m}-1$. Overall, results indicated that the electrical conductivity in sewage irrigated soils indicate irregular distribution pattern towards total dissolved salts. We can say that soils belong to sewage areas were non saline in nature because of well drain soils and soils belongs to silty clay to clay loam.

Thereby, salt deposited on upper surface, leach down to lower horizon due to coarse textural fragments. Apart from these, low value of total dissolved salt was observed due to loss of soluble salts with run-off and flood water especially in fluvial plain and leaching of soluble salts after rain recedes (Sangawan 1988, Das, 1989 and Singh et al., 2000). 


\section{SOC}

In Kalupur village, the soil organic carbon ranged from 0.23 to 1.04 percent with a mean value of 0.60 percent. The maximum value (1.04 percent) was found in $\mathrm{P}_{2}$ at a depth of $60-90 \mathrm{~cm}$. Whereas, the minimum value of soil organic carbon (0.23 percent) was observed in $\mathrm{P}_{3}$ at a depth of $60-90 \mathrm{~cm}$. In Basantpur village, the soil organic carbon of pedonvaried from 0.13 to 0.84 percent with a mean value of 0.40 percent.

The maximum value was observed in $\mathrm{P}_{6}$ at a depth of $60-90 \mathrm{~cm}$ while minimum value (0.13 percent) was obtained at $15-30 \mathrm{~cm}$ depth in $\mathrm{P}_{4}$. Similarly, the SOC of pedon varied from 0.35 to 1.28 percent with a mean value of 0.64 percent in Mathurapur village. The maximum value (1.28 percent) was observed at a depth of $0-15 \mathrm{~cm}$ in $\mathrm{P}_{7}$. While, minimum value i.e., 0.35 percent was observed at a depth of $45-60 \mathrm{~cm}$ in $\mathrm{P}_{8}$. The irregular pattern was observed in all selected pedon in sewage irrigated areas in Nathnager block.

However, SOC from sewage irrigated soils of some selected village in Nathnager block were varied from 0.13 to 1.28 with mean value 0.54 percent. Overall, results indicated that organic carbon content in all selected Pedon (P1 to P9) decreased with increasing depth except few. The higher concentration of organic carbon content in upper layer may be due to more deposition of sewage effluent in upper layer and it attributes huge number of enormous nutrients.

These results are in agreement with the findings of the present study by various scientist and they found that significantly higher organic carbon in sewage irrigated soil due to the addition of carbonaceous material (Malik et al., 2004 and Yadav et al., 2003). They further reported that significantly an increase in carbon content of soil with continuous addition of sewage water which may be due to the addition of biomass present in irrigational water. It can be concluded that fast decomposition of organic matter under tropical climate (Kaswala and Despande 1986, Prasad et al., 1986) and leading to formation of $\mathrm{CO}_{2}$ and $\mathrm{H}_{2} \mathrm{O}$.

\section{Fertility status of major Nutrients}

The fertility status of some selected pedon in sewage irrigated soils in Nathnager block were interpreted and results found observed that nitrogen status was varied from $98 \mathrm{~kg} \mathrm{ha}^{-}$ ${ }^{1}$ to $263 \mathrm{~kg} \mathrm{ha}^{-1}$ with mean $164 \mathrm{Kg} \mathrm{ha}^{-1}$. In Kalupur village, the available nitrogen of pedon varied from 100 to $200 \mathrm{~kg} \mathrm{ha}^{-1}$ with a mean value $153 \mathrm{~kg} \mathrm{ha}^{-1}$.

The maximum value $\left(200 \mathrm{~kg} \mathrm{ha}^{-1}\right)$ was found at a depth of $0-15 \mathrm{~cm}$ in $\mathrm{P}_{3}$ while the minimum value $\left(100 \mathrm{~kg} \mathrm{ha}^{-1}\right)$ was obtained at a depth of $30-45 \mathrm{~cm}$ in $\mathrm{P}_{1}$. In Basantpur village, the available nitrogen of pedon varied from $122 \mathrm{~kg} \mathrm{ha}^{-1}$ to $263 \mathrm{~kg} \mathrm{ha}^{-1}$ with a mean value $173 \mathrm{~kg} \mathrm{ha}^{-1}$.

The maximum value $\left(263 \mathrm{~kg} \mathrm{ha}^{-1}\right)$ was found at a depth of $0-15 \mathrm{~cm}$ in $\mathrm{P}_{5}$ and $\mathrm{P}_{6}$. Whereas, the minimum value of available $\mathrm{N}(122 \mathrm{~kg} \mathrm{ha}$ ${ }^{1}$ ) of pedon was observed at a depth of 15-30 $\mathrm{cm}$ and $60-90 \mathrm{~cm}\left(\mathrm{P}_{4}\right.$ andP $\left.\mathrm{P}_{6}\right)$, respectively. In Mathurapur village, the available nitrogen of pedon varied from 98 to $248 \mathrm{~kg} \mathrm{ha}^{-1}$ with a mean value $167 \mathrm{~kg} \mathrm{ha}^{-1}$. The maximum value $\left(248 \mathrm{~kg} \mathrm{ha}^{-1}\right)$ was found at depth of 60-90 cm in $\mathrm{P}_{7}$ while the minimum value $\left(98 \mathrm{~kg} \mathrm{ha}^{-1}\right)$ was obtained at a depth of $0-15 \mathrm{~cm}$ in $\mathrm{P}_{7}$.

Overall, results indicated that most of the selected pedon in sewage irrigated soils belongs to too low status. In Kalupur village, the available phosphorus of pedon varied from 15 to $154 \mathrm{~kg} \mathrm{ha}^{-1}$ with a mean value of $90 \mathrm{~kg} \mathrm{ha}^{-1}$. 
Table.1 Physiochemical properties of pedon in sewage irrigated soils

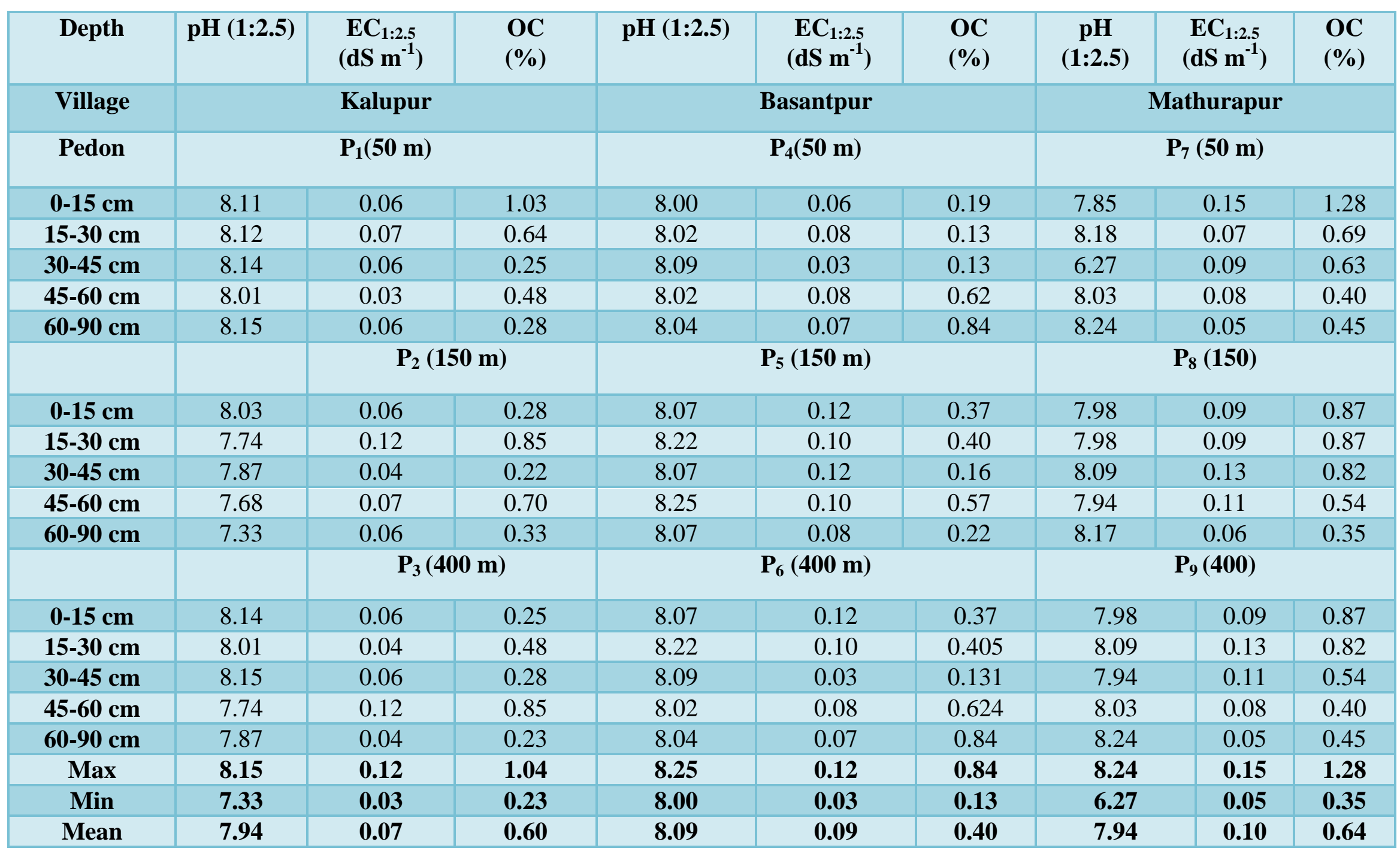


Table.2 Fertility status of pedon in sewage irrigated areas

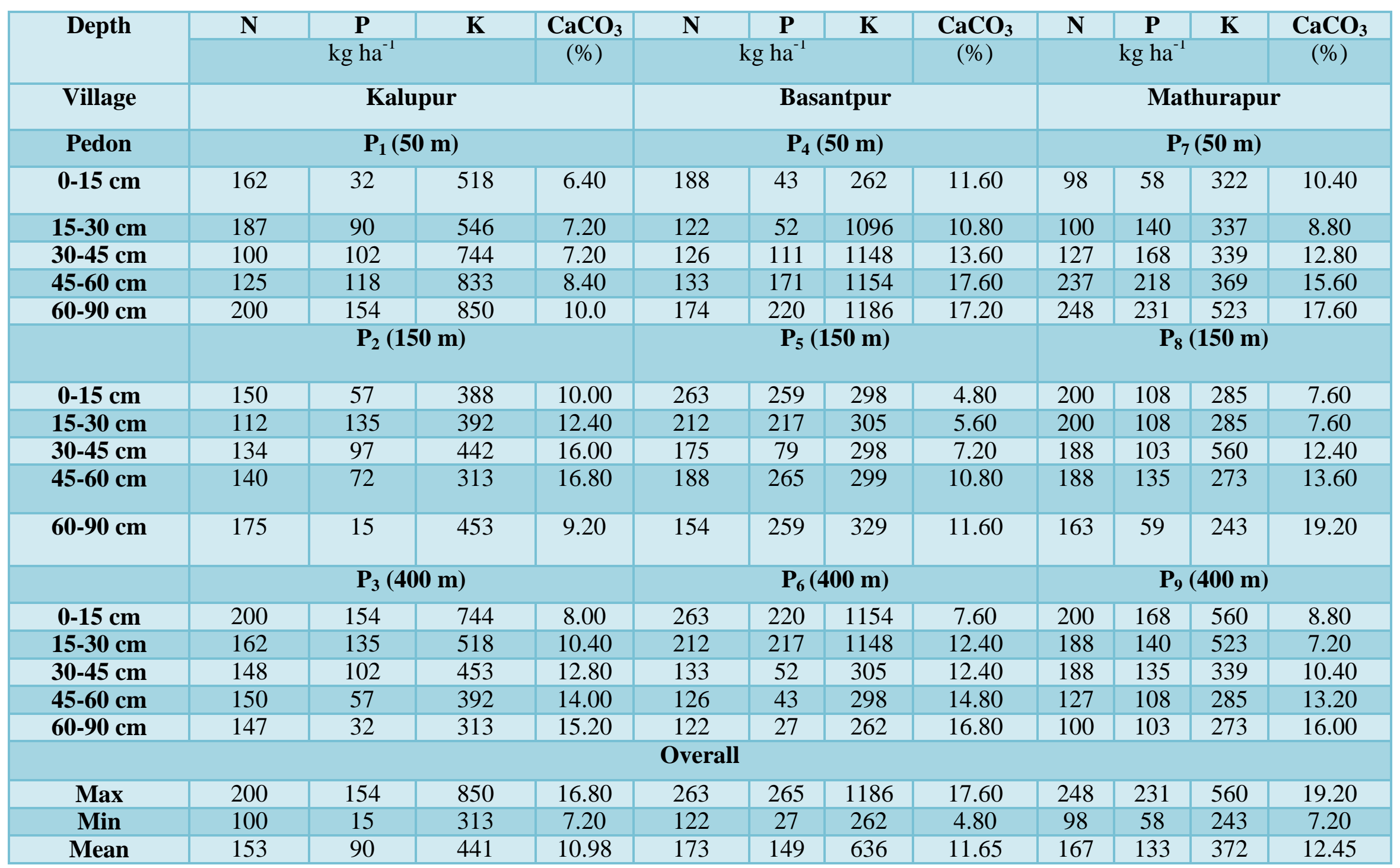




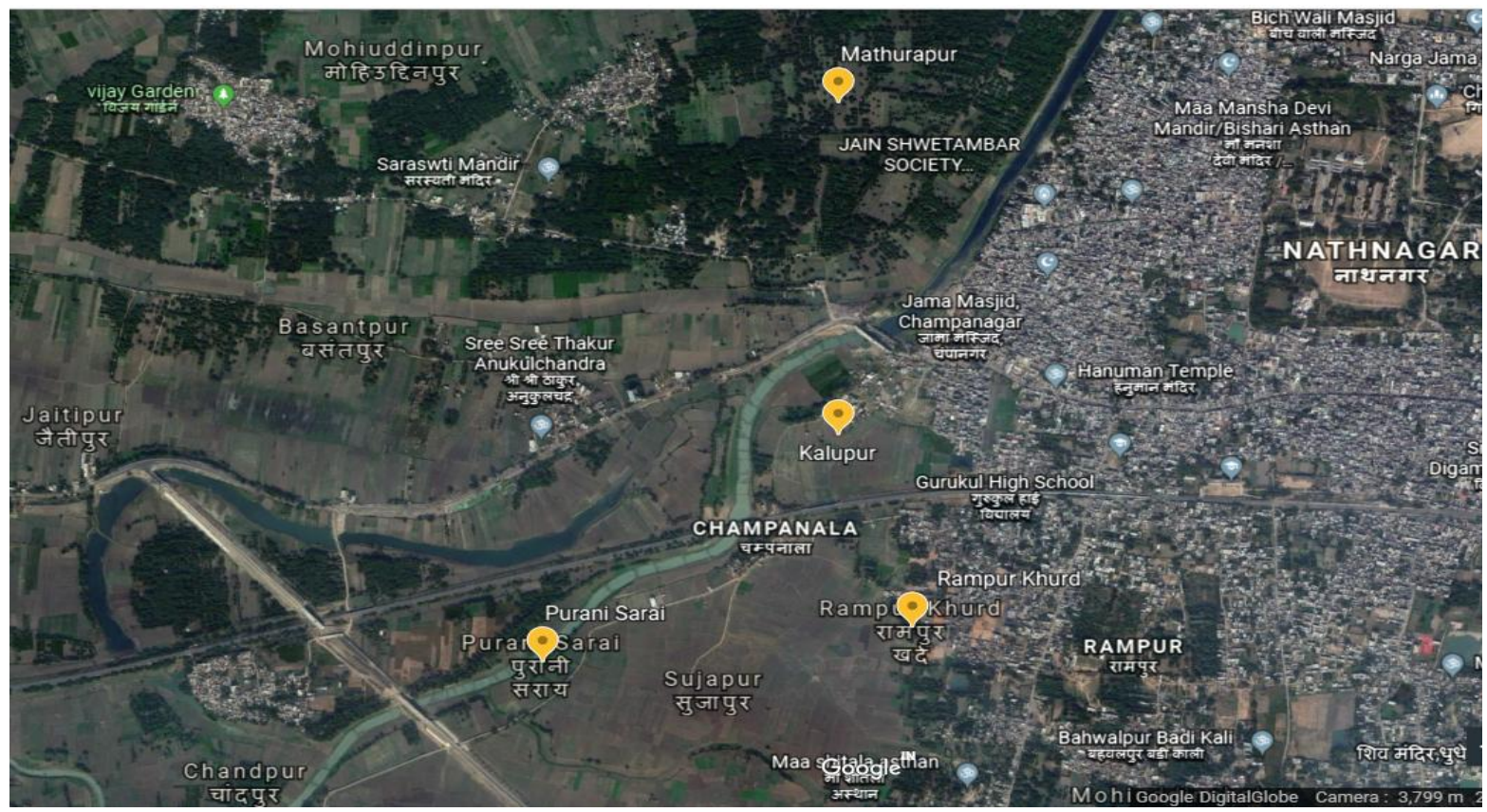

Fig.1 Location map of sewgae irrigated soils in Nathnager block

The maximum value (154 $\left.\mathrm{kg} \mathrm{ha}^{-1}\right)$ was observed at 60-90 cmand 0-15 cm depth in $\mathrm{P}_{1}$ and $\mathrm{P}_{3}$, respectively, whereas minimum value $\left(15 \mathrm{~kg} \mathrm{ha}^{-1}\right)$ was found at $60-90 \mathrm{~cm}$ depth in $\mathrm{P}_{2}$.In Basantpur village, the available phosphorus of pedon varied from 27 to 265 $\mathrm{kg} \mathrm{ha}^{-1}$ with a mean value of $149 \mathrm{~kg} \mathrm{ha}^{-1}$. The maximum value $\left(265 \mathrm{~kg} \mathrm{ha}^{-1}\right)$ was observed at 45-60 cmdepth in $\mathrm{P}_{5}$.

Whereas, minimum value $27 \mathrm{~kg} \mathrm{ha}^{-1}$ was found at $60-90 \mathrm{~cm}$ depth in $\mathrm{P}_{6}$. In Mathurapur village, the available phosphorus of pedon varied from $58 \mathrm{~kg} \mathrm{ha}^{-1}$ to $231 \mathrm{~kg} \mathrm{ha}^{-1}$ with a mean value of $\left(133 \mathrm{~kg} \mathrm{ha}^{-1}\right)$.

The maximum value (231 $\mathrm{kg} \mathrm{ha}^{-1}$ ) was observed at $60-90$ cmdepth in $\mathrm{P}_{7}$. Whereas minimum value $\left(58 \mathrm{~kg} \mathrm{ha}^{-1}\right)$ was found at 0 $15 \mathrm{~cm}$ depth in $\mathrm{P}_{7}$. Whereas, $\mathrm{P}_{2} \mathrm{O}_{5}$ content of sewage irrigated soils was varied from $15 \mathrm{~kg}$ ha $^{-1}$ to $265 \mathrm{~kg} \mathrm{ha}^{-1}$ with mean $124 \mathrm{~kg} \mathrm{ha}^{-1}$. Overall, results indicated that $\mathrm{P}_{2} \mathrm{O}_{5}$ content of selected pedon was high because of advocate of huge amount of phosphate fertilizer by farmers apart from dye and silk industry in Nathnager block.
In Kalupur village, the available $\mathrm{K}_{2} \mathrm{O}$ of pedon varied between 313 to $850 \mathrm{~kg} \mathrm{ha}^{-1}$ with a mean value of $441 \mathrm{~kg} \mathrm{ha}^{-1}$. The maximum value $\left(850 \mathrm{~kg} \mathrm{ha}^{-1}\right)$ was found at a depth of $60-90 \mathrm{~cm}$ in $\mathrm{P}_{1}$. While, the minimum value $\left(313 \mathrm{~kg} \mathrm{ha}^{-1}\right)$ was observed at depth of (45-60 $\mathrm{cm}$ and 60-90 cm) in $\mathrm{P}_{2}$ and $\mathrm{P}_{3}$, respectively. In Basantpur village, the available $\mathrm{K}_{2} \mathrm{O}$ of pedon varied between 262 to $1186 \mathrm{~kg} \mathrm{ha}^{-1}$ with a mean value of $636 \mathrm{~kg} \mathrm{ha}^{-1}$.

The maximum value $\left(1186 \mathrm{~kg} \mathrm{ha}^{-1)}\right.$ was found at depth of $60-90 \mathrm{~cm}$ while minimum value $\left(262 \mathrm{~kg} \mathrm{ha}^{-1}\right)$ was observed at $0-15 \mathrm{~cm}$ at depth of $60-90 \mathrm{~cm}\left(\mathrm{P}_{4}\right.$ and $\left.\mathrm{P}_{6}\right)$,respectively. In Mathurapur village, the available $\mathrm{K}_{2} \mathrm{O}$ of pedon varied between from $243 \mathrm{~kg} \mathrm{ha}^{-1}$ to 560 $\mathrm{kg} \mathrm{ha}^{-1}$ with a mean value of $372 \mathrm{~kg} \mathrm{ha}^{-1}$. The maximum value $\left(560 \mathrm{~kg} \mathrm{ha}^{-1}\right)$ was observed at a depth of $30-45 \mathrm{~cm}$ and $0-15 \mathrm{~cm}\left(\mathrm{P}_{8}\right.$ and $\left.\mathrm{P}_{9}\right)$, respectively.

While, minimum value (243 $\mathrm{kg} \mathrm{ha}^{-1}$ ) was observed at $60-90 \mathrm{~cm}$ in $\mathrm{P}_{8}$. The high status of $\mathrm{K}_{2} \mathrm{O}$ of sewage irrigated soils of some selected pedon in sewage irrigated soils and value was varied from $243 \mathrm{~kg} \mathrm{ha}^{-1}$ to $1186 \mathrm{~kg}$ 
$\mathrm{ha}^{-1}$ with mean $483 \mathrm{kgha}^{-1}$. The significant high status of potassium was observed due to the organic detritus associated with potassium entered the system through leaching (Walker, 1987).

Generally, factors like disposal of sewage water, poultry waste and decay of vegetation can increase the significant concentration of potassium status in sediments. It can be justifying that organic rich effluents enhance the NPK values in the soils after advocate of irrigation system (Mc Bride, 1995). They further reported that, significant amount of feldspar and hydrous mica governing the high potassium status (Diwakar, 1988) in soils of Nathnager block. Walia and Chamuah (1987) reported that high potassium status governs due to micaceous parent material predominate in soils of Bihar and Assam.

From ongoing discussion, we can conclude that, most of the samples from adjoining areas of sewage irrigated soils were deficient in nitrogen, medium to high in phosphate and sufficient in potash status. Thereby, we can say that sewage irrigated soils having sufficient in phosphate and potash but it can use after proper treatments specially for vegetables grower adjoining areas in chapanal pool of Nathnager block.

\section{References}

Aydin, M.E., Aydin, S.Beduk,FTor, A., Tekinay, A., Kolb, M. and Bahadir, M. 2015. Effects of long-term irrigation with untreated municipal wastewater on soil properties and crop quality. Environmental Science Pollution Research, 22:19203-19212.

Chamuah, G.S. 1987. Potassium status of some rice growing soils. Journal of the Indian

CPCB, 2016.Status on Sewage Generation in Metropolitan Cities,Class-I Cities and
Class-II Towns.

Das, S.R., 1989 Fertility status of Barhiya Tal. M. SC (Ag.). Thesis, Rajendra Agricultural University, Bihar.

Diwakar, O.P.S. 1988. Studies on some heavy soils of different origin of Bihar with special reference to their genesis, characterisation and classification. A Ph.D. Thesis, R.A.U, Bihar.

Gomez, A. and Gomez, A.A. 1984. Statistical Process for Agricultural Research. John Willey and Sons, New York. 335.

Hanway, J. J. and H. Heidal 1952. Soil analysis, as used in lowa State. College of Soil Testing Laboratory, lowa. Agriculture, 57 : 1-31.

Jackson, M.L. (1967, 1973). Soil Chemical Analysis, New Delhi Prentice Hall of India.

Kaswala, R.R. and Deshpande S.B., 1986. Silt and clay mineralogy of black alluvial soils of South Gujarat. Journal of the Indian Society of Soil Science, 34:160168.

Malik, A. 2004. Metal bioremediation through growing cells. Environ. Int.30, 261-278.

Bride,Mc.1995. Toxic metal accumulation from agricultural use of sludge: Are the USEPA regulations protective. Journal of Environmental Quality, 24:5-18.

NCIWRD,1999.WithdrawalofFreshhttps://pib .gov.in/newsite/PrintRelease.aspx?relid $=101519$

Olsen, S.R., Cole, C.V., Watanabe, F.S. and Dean, L.A., 1954. Estimation of available phosphorus in soils of extraction with sodium bicarbonate. Cire.U. S. Dep. Agric. 939.

Prasad, S.N, Sahi, B. P and Singh, S.P. 1986. Forms and response of applied $\mathrm{P}$ to wheat in vertisols of Bihar. Indian Society of Soil Science34(2): 297.

Sangwan, P.S., Kuhad, M.S., Sangwan, B.S. and Karwasra, S.P.S., 1988. Geomorphology soil and land use 
studies in the southern part of Mahendragarh district, Haryana, Journal of Indian Society of Soil Science,36(2):296-302.

Sharma, S.S., Totawat, K.L. and Shyampura, R.L., (2004) Characterization and classification of salt-affected soils of Southern Rajasthan Journal of Indian Society of Soil Science 52 (3): 209-214. Singh, R.N. and Singh, R.N.P. and Diwakar, D.P.S., 2000. Characterization of old alluvial soils of Sone basin, Indian Society of Soil Science 48 (2): 352-357. Indian Society of Soil Science 35: 129131.

Subbiah, B.V. and Asija, G. L., 1956. A rapid procedure for the detennination of available nitrogen in soils.Current Science, 25: 259-260.

UnitedNation,2019.http://statisticstimes.com/ demographics/countries-by-populationdensity.php

Walker, I. 1987. Conclusion. The forest as a functional entity. Experientia, 43(3):287-290.

Walkley, A. and Black, I.A., 1934. An Examination of the Degtjareff Method for Determining Soil Organic Matter and a Proposed Modification of the Chromic Acid Titration Method. Soil Science, 37, 29-38.

\section{How to cite this article:}

Sneha, Raj Kishore Kumar, Y. K. Singh, Shweta Shambhavi and Singh. M. K. 2020. Fertility Status of Sewage Irrigated Soils of Adjoining Areas of Nathnager Blocks, Bhagalpur District, India. Int.J.Curr.Microbiol.App.Sci. 9(03): 1401-1409.

doi: https://doi.org/10.20546/ijcmas.2020.903.163 